\title{
Increasing identity and community awareness in Medan City about victim rights of sexual violence
}

\author{
Ningrum Natasya Sirait ${ }^{1 *}$, Rosmalinda ${ }^{1}$, Edy Ikhsan $^{1}$, Mahmul Siregar $^{1}$, Agusmidah $^{1}$ \\ ${ }^{1}$ Faculty of Law, Universitas Sumatera Utara, Medan, Indonesia \\ *Email: ningrum.sirait@gmail.com
}

\begin{abstract}
Indonesia currently has Law Number 11 of 2012 concerning the Criminal Justice System for Children (UUSPPA) to provide protection for children who need special protection such as child offenders, victims and witnesses. In fact, the implementation of the UU-SPPA actually only focuses on children as perpetrators. This not only shows that justice for children is still not upright especially for children who are victims of sexual violence. This is evident from the findings of a study conducted in 2019 entitled "The Effectiveness of the Convention on the Rights of the Child Victims of Sexual Violence". This study found that although Indonesia already has 2 government regulations governing the fulfillment of victims of sexual violence in the form of compensation and or restitution, none of the decisions of the Medan District Court and Lubuk Pakam contain the rights of victims. The decisions of the Medan District Court and Lubuk Pakam throughout 2018 were oriented towards providing penalties for the perpetrators. The two Government Regulations which are guidelines for implementing the Law are (a) Government Regulation of the Republic of Indonesia Number 7 of 2018 concerning Provision of Compensation, Restitution and Assistance to Witnesses and Victims; and (b) Government Regulation of the Republic of Indonesia Number 43 Year 2017 Concerning Implementation of Restitution for Children Who Are Victims of Criminal Acts. These two Government Regulations are the basic ingredients for the implementation of the 2019 Mandatory Servant Lecturer service dedication. This situation is the basis of community service in two districts namely Medan Baru and Medan Sunggal. Law Enforcement Officials (APH) in this case the police and the community not only obtain new information about victims' rights but also increase their awareness to guarantee the rights of children victims of sexual violence are requested in legal proceedings for perpetrators. Furthermore, the Police and the community hope that the information on these two Government Regulations can be continued both by the Regional Government Organization (OPD) and other institutions such as the Civil Society Organization (CSO) in Medan.
\end{abstract}

\section{Keyword: Rights of victims of sexual violence, Restitution, Children}

\begin{abstract}
Abstrak
Saat ini Indonesia telah memiliki Undang Undang Nomor 11 Tahun 2012 tentang Sistem Peradilan Pidana Anak (UU-SPPA) untuk memberikan perlindungan bagi anak yang membutuhkan perlindungan khusus seperti anak pelaku, korban maupun saksi. Faktanya, pelaksanaan UU-SPPAternyata hanya berfokus pada anak sebagai pelaku. Hal ini tidak hanya memperlihatkan bahwa keadilan bagi anak masih belum tegak khsususnya bagi anak korban kekerasan seksual. Hal ini terbukti dari temuan penelitian yang dilakukan pada tahun 2019 yang berjudul "Efektifitas Pelaksanaan Konvensi Hak Anak Korban Kekerasan Seksual". Penelitian ini menemukan bahwa meskipun Indonesia telah memiliki 2 peraturan pemerintah yang mengatur tentang pemenuhan hak korban kekerasan seksual berupa kompensasi dan atau restitusi, tidak ada satupun putusan Pengadilan Negeri Medan dan Lubuk Pakam yang memuat hak korban. Keputusan-keputusan PN Medan dan Lubuk Pakam sepanjang tahun 2018 berorientasi pada pemberian hukuman bagi pelaku. Kedua Peraturan Pemerintah yang merupakan petunjuk pelaksana Undang Undang yaitu (a) Peraturan Pemerintah Republik Indonesia Nomor 7 Tahun 2018 Tentang Pemberian Kompensasi, Restitusi, Dan Bantuan Kepada Saksi Dan Korban; dan (b) Peraturan Pemerintah Republik Indonesia Nomor 43 Tahun 2017 Tentang Pelaksanaan Restitusi Bagi Anak Yang Menjadi Korban Tindak Pidana. Kedua Peraturan Pemerintah inilah yang menjadi bahan dasar pelaksanaan pengabdian Skema Dosen Wajib Mengabdi pada tahun 2019 ini. Situasi ini menjadi dasar pelaksanaan pengabdian kepada Masyarakat di dua kecamatan yaitu Medan Baru dan Medan Sunggal. Aparat Penegak Hukum (APH) dalam hal ini Polisi dan masyarakat tidak hanya memperoleh informasi baru tentang hak korban tetapi juga meningkat kesadarannya untuk menjamin hak anak korban kekerasan seksual dimintakan dalam proses hukum bagi pelaku.
\end{abstract}


Lebih lanjut, Polisi dan masyarakat berharap bahwa informasi tentang kedua Peraturan Pemerintah ini dapat dilanjutkan baik oleh Organisasi Pemerintah Daerah (OPD) dan Lembaga lainnya seperti Civil Society Organization (CSO) yang ada di Kota Medan.

Kata Kunci: Hak korban Kekerasan seksual, Restitusi, Anak

\section{PENDAhUluAN}

Indonesia telah meratifikasi Convention on the Right of the Child (CRC) atau lebih dikenal dalam bahasa Indonesia sebagai Konvensi Hak Anak (KHA). KHA merupakan wujud nyata atas pelaksanaan perlindungan hak anak. Artinya, KHA memberikan jaminan kepada setiap anak bahwa Negara akan menghormati, menjamin pemenuhan dan perlindungan anak tanpa kecuali. Konvensi Hak Anak merupakan instrumen hukum yang komprehensif yang mencakup perlindungan hak-hak sipil, politik, ekonomi serta budaya. Secara gamblang, KHA memberikan hak-hak Anak berupa kelangsungan hidup, tumbuh dan berkembang, mendapatkan perlindungan atas segala bentuk kekerasan, serta untuk berpartisipasi di masyarakat. Sebagai salah satu dari 196 negara yang ikut meratifikasi KHA maka pemerintah Indonesia memiliki kedudukan sebagai pemangku kewajiban. Pemerintah Indonesia diamanahkan KHA untuk mengambil semua langkahlangkah legislatif, administratif, sosial dan pendidikan yang layak guna melindungi hak anak dari segala bentuk dan manifestasi kekerasan.

Pada kesempatan ini, Penulis akan fokus pada peran pemerintah Indonesia dalam memberikan perlindungan kepada seluruh anak di Indonesia. Hal ini penting mengingat hasil temuan sebuah penelitian yang berjudul "Efektifitas Pelaksanaan Konvensi Hak Anak Korban Kekerasan Seksual" yang dilaksanakan pada tahun 2019 memperlihatkan bahwa 7 putusan Pengadilan Negeri Medan (PN-Medan) dan Lubuk Pakam (PN-L.Pakam) serta 3 Putusan Pengadilan Tinggi Medan yang telah diputus dan berkekuatan hukum tetap pada tahun 2018 ternyata tidak memuat pemenuhan hak restitusi bagi korban. Hal ini sangat disayangkan mengingat, Indonesia pada tahun 2017 dan 2018 telah memiliki dua Peraturan Pemerintah yang mengatur tentang hak Korban termasuk hak anak korban kekerasan seksual. Kedua ketentuan dimaksud adalah: (a) Peraturan Pemerintah Republik Indonesia Nomor 7 Tahun 2018 Tentang Pemberian Kompensasi, Restitusi, Dan Bantuan Kepada Saksi Dan Korban; dan (b) Peraturan Pemerintah Republik Indonesia Nomor 43 Tahun 2017 Tentang Pelaksanaan Restitusi Bagi Anak Yang Menjadi Korban Tindak Pidana.

\section{METODE PELAKSANAAN}

Anak memiliki kedudukan yang lemah, sehingga menjadikannya sebagai salah satu pihak yang paling rentan terhadap segala bentuk kejahatan yang merendahkan martabat anak sebagai manusia, tak terkecuali kekerasan seksual. Saat ini Indonesia dikategorikan sebagai negara dengan kondisi darurat kekerasan seksual terhadap anak. Mengutip data dari KPAI, ditemukan sebanyak 281 kasus kekerasan seksual pada anak di tahun 2015, 120 kasus di tahun 2016 dan 116 kasus di tahun 2017. Meski mengalami penurunan dari segi kuantitas pada periode 2015-2017, angka kekerasan seksual di Indonesia masih tergolong memperihatinkan. Sedangkan untuk di wilayah Sumatera Utara, Direktur Pusat Kajian dan Perlindungan Anak (PKPA) Sumatera Utara, Misran Lubis, menyatakan bahwa tercatat 295 kasus kejahatan anak pada tahun 2017 menurut advokasi dan pemantauan selama ini, dengan 33\% di antaranya merupakan kasus kekerasan seksual.

Perhatian yang serius sangat diperlukan dalam proses penanganan kasus kekerasan seksual terhadap anak mengingat dampak yang ditimbulkan sangatlah besar dan berjangka panjang, baik dalam segi psikologis, emosional maupun fisik. Komitmen pemerintah Indonesia dalam mengakhiri kekerasan terhadap anak, terutama kekerasan seksual diimplementasikan melalui serta ditunjang oleh peraturan perundang-undangan antara lain UU No. 17 Tahun 2016 tentang Perubahan Kedua atas UU No. 23 Tahun 2002 tentang Perlindungan Anak (UUPA). Perubahan 
Kedua pada UUPA ini secara substansial telah sesuai dengan prinsip serta nilai yang terkandung di dalam Konvensi Hak Anak dalam memberikan perlindungan terhadap anak korban kekerasan seksual. UUPA yang telah mengalami perubahan dua kali termasuk Perubahan pertamanya yaitu UU No 35 tahun 2014 tentang Perubahan UU No. 23 Tahun 2002 tentang Perlindungan Anak (UUPA) telah memberikan hukuman yang lebih tinggi bagi Pelaku kekerasan seksual terhadap Anak.

Situasi dan kondisi yang terjadi di Indonesia ini memperlihatkan bahwa betapa hak anak korban kekerasan seksual masih jauh dari kata terlindungi oleh Negara. Disatu sisi, Indonesia telah mengatur tentang perlindungan Anak korban kekerasan seksual dalam UUPA. Disisi lain, terlihat bahwa angka kekerasan seksual terhadap anak masih tinggi. Ironi pemenuhan hak anak semakin terlihat dari temuan penelitian yang berjudul "Efektifitas Pelaksanaan Konvensi Hak Anak Korban Kekerasan Seksual". Pada laporannya, Penelitian ini menyebutkan bahwa:

"Hasil Penelitian memperlihatkan bahwa tidak ada satupun putusan pengadilan menyebutkan dalam putusannya tentang hak anak korban. Keseluruhan putusan pengadilan hanya focus pada penghukuman Pelaku. Lebih lanjut, FGD menemukan bahwa tidak diputusnya hak anak korban kekerasan seksual oleh Hakim disebabkan tidak adanya permintaan dari pihak korban atas hak korban berupa hak restitusi sesuai Peraturan Pemerintah No 43 Tahun 2017 tentang Pelaksanaan Restitusi bagi Anak yang Menjadi Korban Tindak Pidana. “

Situasi ini tentunya memberikan dampak bagi anak korban kekerasan seksual yang telah mengalami kerugian material dan immaterial seperti rasa malu, kehilangan harga diri, rendah diri, dan/atau kecemasan berlebihan yang bersifat traumatik. Dampak lain yang dialami oleh anak korban kekerasan seksual adalah trauma secara seksual, luka secara fisik, kehamilan yang tidak diinginkan, perilaku cenderung berubah, penyakit menular seksual. Pada beberapa kasus bahkan menimbulkan dorongan bunuh diri, dampak psikologi dan gangguan fungsi reproduksi.

\section{HASIL DAN PEMBAHASAN}

Mendiskusikan tentang Pemenuhan hak anak yang diatur dalam KHA maka adalah keharusan untuk melihat peran Civil Society Oragnization (CSO) seperti Pusat Kajian dan Perlindungan Anak (PKPA). PKPA adalah lembaga yang peduli dengan anak dan melakukan pendampingan bagi anak yang berhadapan dengan Hukum $(\mathrm{ABH})$ sebagaimana diatur dalam Undang Undang Nomor 11 Tahun 2012 tentang Sistem Peradilan Pidana Anak (UU-SPPA). Selama melaksanakan pendampingan $\mathrm{ABH}$, PKPA banyak bekerja bagi anak-anak yang berkonflik dengan hukum dan Korban. PKPA adalah mitra Pengabdian kepada Masayarakat yang dilakukan oleh Tim Pengabdian Kepada Masyarakat. Dalam kemitraannya ini, diketahui bahwa pemenuhan hak anak yang berkonflik dengan hukum dilakukan oleh PKPA dengan menggunakan Undang Undang N0 11 tahun 2012 tentang Sistem Peradilan Pidana Anak. Sedangkan bagi Anak sebagai korban tindak pidana khususnya korban kekerasan seksual PKPA memiliki tantangan tersendiri dalam pemenuhan haknya.

Hal ini dikarenakan APH dan masyarakat (orang tua korban) tidak mengetahui adanya pengaturan tentang pemenuhan Hak-hak korban melalui Putusan Pengadilan Negeri yang dapat dibebankan kepada Pelaku dalam bentuk restitusi. Ketidakpahaman APH khususnya polisi dipertegas saat Tim Pengabdian melakukan komunikasi lebih lanjut dengan Polsek Medan Baru dan Polsek Sunggal terutama saat dilaksanakannya Pengabdian tentang hak-hak anak korban kekerasan seksual berupa restitusi. Hampir seluruh Peserta yang merupakan polisi menyatakan bahwa mereka memiliki beberapa pertanyaan tentang Restitusi sebagai Hak anak korban kekerasan seksual. Pertanyaan-Pertanyaan yang diajukan selama proses Pengabdian cukup menarik mengingat peserta baru mengetahui keberadaan Peraturan pemerintah yaitu (a) Peraturan Pemerintah Republik Indonesia Nomor 7 Tahun 2018 Tentang Pemberian Kompensasi, Restitusi, Dan Bantuan Kepada Saksi Dan Korban; dan (b) Peraturan Pemerintah Republik Indonesia Nomor 43 Tahun 2017 Tentang Pelaksanaan Restitusi Bagi Anak Yang Menjadi Korban Tindak Pidana. 
Permasalahan yang menjadi tantangan pemenuhan hak anak yang dilakukan oleh PKPA dan Kepolisian dijawab melalui beberapa kegiatan. Pertama, penyusunan modul (buku panduan) yang berisi materi pembelajaran, berisi dasar-dasar aturan dan konsep berkaitan dengan Hak-hak korban kekerasan seksual khususnya anak dan tata cara pengajuan restitusi bagi korban melalui berkas tuntutan di Pengadilan Negeri (PN). Kedua, sosialiasi pengetahuan tentang Hak-hak korban seksual khususnya Anak. Sosialisasi ini dilakukan berupa penyuluhan Hukum menggunakan buku panduan/modul yang telah disusun sebelumnya. Untuk mengetahui efektifitas pelaksanaan pengabdian kepada masyarakat maka dilakukan pengukuran kemampuan tentang informasi terkait hak-hak anak kepada peserta. Pengukuran dilakukan dengan bertanya diawal penyuluhan hukum tentang hak-hak anak korban kekerasan seksual termasuk restitusi. Selanjutnya, pada akhir penyuluhan hukum, peserta kembali diminta pendapatnya tentang pelaksanaan kegiatan khususnya tentang informasi yang telah disampaikan yaitu restitusi korban kekerasan seksual. Teknik pengukuran yang berutujuan untuk mengetahui peningkatan pemahaman dan pengetahuan peserta ini disebut pre-test dan post-test.

Ketiga, proses penyuluhan Hukum, Pesertas dipersilahkan untuk berdiskusi dengan memberikan pertanyaan. Beberapa pertanyaan yang menarik dan membutuhkan tindak lanjut antara lain: (a) Bagaimana pengaturan tetang Restitusi?. (b) Sebagai seorang polisi, apa yang sebaiknya dilakukan oleh Polisi saat Pelapor yang merupakan orang tua atau keluarga anak korban kekerasan seksual menyatakan bahwa pelaku adalah tetangga mereka miskin. Sebagaimana diketahui, restitusi yang diatur dan kedua peraturan pemerintah mewajibkan pelaku untuk membayar biaya restitusi yang diputus oleh Pengadilan. Kedua pertanyaan ini sangat penting menjadi perhatian mengingat pengaturan restitusi ini belum pernah dilakukan di Kota Medan. Temuan saat melakukan pengabdian kepada masyarakat ini menjadi rekomendasi dari pelaksanaan kegiatan pengabdian. Tahap ini merupakan tahap ke-empat yaitu membangun kerjasama antara PKPA dengan Tim Unit PPA di 2 Polsek dalam wilayah Polsekta Medan dan sekitarnya untuk memasukkan hak korban dalam berkaas perkara di PN Medan.

\section{KESIMPULAN}

Pelaksanaan Pengabdian kepada Masyarakat ini telah memberikan beberapa poin penting yang menjadi catatan dalam tulisan ini, yaitu:

1. Minimnya pengetahuan APH dan Masyarakat tentang (a) Peraturan Pemerintah Republik Indonesia Nomor 7 Tahun 2018 Tentang Pemberian Kompensasi, Restitusi, Dan Bantuan Kepada Saksi Dan Korban. (b) Peraturan Pemerintah Republik Indonesia Nomor 43 Tahun 2017 Tentang Pelaksanaan Restitusi Bagi Anak Yang Menjadi Korban Tindak Pidana.

2. Minimnya Pengetahuan APH tentang cara pengajuan Hak korban dalam berkas tuntutan Pidana di Pengadilan Negeri.

Adapun rekomendasinya adalah:

1. Meningkatkan Pengetahuan APH dan Masyarakat tentang hak-hak korban kekerasan seksual khususnya Anak 50 orang dari mitra yang berada di dua kecamatan (a) Medan Baru dan (b) Medan Sunggal dengan membagikan 100 eks buku saku tentang Hak-hak Korban Kekerasan Seksual khususnya Anak.

2. Meningkatkan pengetahuan tentang cara pengajuan Hak korban dalam berkas tuntutan Pidana di Pengadilan Negeri untuk itu dibutuhkan kerjasama antara PKPA dengan Penyidik pada dua Unit PPA di Polsek dalam wilayah Polsekta Medan dan Sekitarnya.

\section{UCAPAN TERIMAKASIH}

Artikel ini merupakan salah satu hasil dari Program Pengabdian kepada Masyarakat yang Dibiayai oleh dana NON PNBP Universitas Sumatera Utara. Oleh karena itu, diucapkan terima kasih kepada 
Rektor Universitas Sumatera Utara atas dukungan dana dan fasilitas yang diberikan. Terima kasih juga kepada Mitra pada kegiatan pengabdian ini.

\section{DAFTAR PUSTAKA}

Australia Indonesia Partnership for Justice dan MAPPI FH UI, Kekerasan Seksual di Indonesia: Data, Fakta, dan Realita, 2016

Budijanto, Oki Wahju, 2013, "Efektifitas Forum Dilkumjakpol dalam Kerangka Integrated Criminal Justice System”, Jurnal HAM, Volume 4 No 1.

Davidson, Julia C., 2008, "Child Sexual Abuse Media Representations and Government Reactions", Routledge-Cavendish, Inggris.

Davit Setyawan, "Tahun 2017, KPAI Temukan 116 Kasus Kekerasan Seksual Terhadap Anak", diakses dari http://www.kpai.go.id/berita/tahun-2017-kpai-temukan-116-kasuskekerasan-seksual-terhadap-anak, pada 03 Februari 2019.

Direktorat Jendral Cipta Karya, "Profil Wilayah Kota Medan".

Itah, Israr, "Kejahatan Anak di Sumut Meningkat Drastis", diakses dari https://www.republika.co.id/berita/nasional/daerah/18/01/01/p1v481348-kejahatanterhadap-anak-di-sumut-meningkat-drastis, pada 03 Februari 2019.

Noviana, Ivo, 2015, “Kekerasan Seksual Terhadap Anak: Dampak dan Penanganannya", Jurnal, hal. 15.

Pemerintah Kota Medan, "Kependudukan", diakses dari https://pemkomedan.go.id/halkependudukan.html, pada 5 Februari 2019.

Peraturan Pemerintah Nomor 43 Tahun 2017 tentang Pelaksanaan Restitusi Bagi Anak yang Menjadi Korban Tindak Pidana

Rosmalinda, Ningrum Natasya Sirait, Edy Ikhsan, 2019 Laporan Penelitian berjudul "Efektifitas Pelaksanaan Konvensi Hak Anak Korban Kekerasan Seksual", Unpublished

Sunarto, 1990, “Metode Penelitian Deskriptif”, Usaha Nasional, Surabaya.

UNICEF, “The State of the World's Children: Special Edition (UNICEF 2009)".

United Nations, 1993, “A Compilation of International Instruments Volume I (First Part)". 